\title{
Current plantation practices have negligible genetic effects on planted dipterocarps in the tropical rainforest
}

\author{
By A. IZUnO ${ }^{1), 2)}$, S. IndRioko ${ }^{3)}$, WidiYatno $^{3)}$, E. Prasetyo ${ }^{3)}$, KASMUJiono $^{4)}$ and Y. IsaGi ${ }^{1)}$
}

(Received 15 $5^{\text {th }}$ May 2013)

\begin{abstract}
Dipterocarp trees are ecologically and commercially important in Southeast Asian tropical rainforests. For sustainable management of forest ecosystems and conservation of biodiversity, it is essential to establish plantation methods ensuring that genetic variation of the planted trees is equivalent to that in natural forests. The genetic diversity and differentiation of Shorea leprosula and Shorea parvifolia on plantations managed by a private-sector forestry company in Indonesia and those in natural populations were compared using microsatellite markers. Genetic diversity in the planted populations was as high as that in the natural populations. No clear genetic differences between each planted population and the natural forest populations were found. The genetic variation present in planted S. leprosula and S. parvifolia populations did not appear to deteriorate in the planting system implemented in Indonesia, known as Tebang Pilih Tanam Jalur (TPTJ). These results indicate that the current plantation method practiced in the region is suitable for maintaining the original genetic composition and achieving sustainable use of tropical rainforests.
\end{abstract}

Key words: genetic diversity, plantation, Shorea, Southeast Asia, tropical rainforest.

\section{Introduction}

Southeast Asia is recognized as one of the major biodiversity hotspots in the world (MYERS et al., 2000; FISHER et al., 2011b). Since 2000, deforestation of lowland rainforest has become more serious in this region that in other tropical regions (BRADSHAW et al., 2009). Furthermore, this deforestation is expanding and accelerating (FISHER et al., 2011a), primarily because of illegal logging and burning of forests to obtain agricultural land (KETTLE et al., 2011). Therefore, planting after cutting is important: planted forests presently cover more forest area than primary forests (ITTO, 2005). In addition to the protection of primary forests, maintenance of planted forests is recognized as an effective strategy for conservation of biodiversity (BARLOW et al., 2007; MEIJAARD and SHEIL, 2007) and mitigation of the effects of climate change (BERRY et al., 2010).

\footnotetext{
1) Graduate school of Agriculture, Kyoto University, Kitashira kawa Oiwake-cho Sakyo-ku, Kyoto 606-8502, Japan.

$\left.{ }^{2}\right)$ Research Fellow of Japan Society for the Promotion of Science.

$\left.{ }^{3}\right)$ Faculty of Forestry, Gadjah Mada University, Jl. Agro No. 1 Bulaksumur Yogyakarta 55281, Indonesia.

4) PT Sari Bumi Kusuma, Jl. Adisucipto Km 5.3 P. O. Box 16, Pontianak, Kalimantan Barat, Indonesia.

*) Corresponding author: AyaKo IzUno.

Tel \& Fax: +81-75-753-6129. E-Mail: izunoay@gmail.com
}

Dipterocarp trees are important resources, both ecologically and commercially, in the Southeast Asian tropical rainforest. The family Dipterocarpaceae is classified into 13 genera, approximately 475 species of which can be found in Southeast Asia (BAWA, 1998; AsHTON, 2004). Dipterocarp trees are dominant over substantial areas of the forests in this region and constitute the core elements of biodiversity in tropical ecosystems. Dipterocarp trees are also important timber trees and account for $80 \%$ of timber exports from the region (KETTLE, 2010). Therefore, developing a sustainable system for dipterocarp timber production will contribute not only to the maintenance and improvement of the economic activities of rural residents but also to the conservation of biodiversity.

Until recently, planting and efforts to enhance timber production from dipterocarp trees have been unsuccessful (APPANAH, 1998). One problem was an inconsistent supply of seeds and seedlings because of irregular flowering and fruiting, a short viability period (ADJERS and OTSAMO, 1996), poor seed quality resulting from frequent insect and fungal attacks (SAKAI, 1980; TOMPSETT, 1987), and lack of seed storage and handling facilities (NG, 1977). However, forest concession companies have introduced good nursery facilities for storage of wild seedlings (wildlings) collected during mass flowering years and have successfully managed commercial dipterocarp plantations. Determination of optimal plantation conditions such as tree density, light conditions, and soil humidity has also been another problem. For example, in Indonesia, one of the silviculture system used to manage tropical rainforests is selective cutting and strip planting (Tebang Pilih Tanam Jalur, TPTJ). TPTJ was introduced in 1998 (MINISTRY OF FORESTRY, 1998) and modified in 2005 and 2009 as Indonesia Selective Cutting and Intensive Planting System (Tebang Pilih Tanam Indonesia Intensif, TPTII) and TPTJ with Silviculture Technique, respectively (MINISTRY OF FORESTRY, 2005; Ministry OF Forestry, 2009). In these systems, enrichment planting is conducted in strips planting in order to increase the density of desired tree species in secondary forests (Sovu et al., 2010). Trees are planted at the following varied intervals: $5 \times 25 \mathrm{~m}$ (80 trees/ha), $2.5 \times 20 \mathrm{~m}$ (200 trees/ha), and $5 \times 20 \mathrm{~m}$ (100 trees/ha) for TPTJ 1998, TPTII, and TPTJ 2009, respectively (MINISTRY OF FORESTRY, 1998; MINISTRY OF FORESTRY, 2005; HARDiAnsyah et al., 2006; Ministry OF ForESTRY, 2009). As a result of the improved guidelines for growing wild seeds in nurseries and the enforcement of the TPTJ system, the cultivation of planted trees has become a sustainable enterprise.

Although strategies for tree planting in plantations have been considerably optimized, the genetic composi- 
tion of planted trees has not been specifically studied. In the case of planting individuals of native plant species that have originated from wild rather than genetically improved seeds and seedlings, the following two genetic aspects should be considered: genetic diversity within and genetic differentiation among populations. Genetic diversity is essential for conservation of genetic resources, resistance to various pests in natural ecosystems, avoidance of inbreeding depression (FRANKHAM, 1995), and ecosystem-specific processes including community production and maintenance of floral and faunal diversity (CRUTSINGER et al., 2006). These advantages are ecologically and economically important because population variability is needed for long-term timber harvesting. Moreover, genetic differentiation between the plantations and the surrounding natural forests should be considered (O'BRIEN et al., 2010). Even within a single species, genetic differentiation exists between subpopulations because of local adaptations and/or genetic drift (LINHART and GRANT, 1996). If individuals are introduced to a plantation site from genetically differentiated populations, growth rate and/or population fitness may decrease (HUFFORD and MAZER, 2003). In the event that the resulting generations grow successfully at the plantation site, genetic crossing with naturally grown individuals may lead to genetic pollution or disturbance of the genetic structure and outbreeding depression in the natural forests (HUFFORD and MAZER, 2003; PотTs et al., 2003). Therefore, planted populations should have a similar genetic composition to those present in the natural forests.

Shorea leprosula Miq. and S. parvifolia Dyer (Dipterocarpaceae) are common species in the lowland rainforests of Southeast Asia and are known as useful timber species because of their high growth rates and ease of processing for lumber. In this study, we analyzed the genetic composition of $S$. leprosula and $S$. parvifolia planted in Central Kalimantan, Indonesia. We then compared these characteristics with those of the natural populations in the same region. Our objective was to investigate whether the current method for planting dipterocarp trees in the region is adequate to maintain genetic diversity and avoid genetic differentiation from the surrounding natural forest.

\section{Materials and Methods}

\section{Plant materials and study site}

Plant materials for DNA analysis were collected at the concession area managed by PT Sari Bumi Kusuma (SBK), a private forestry company located in Central Kalimantan (Fig. 1). SBK manages approximately $148 \mathrm{~km}^{2}$ of the concession area and harvests timbers of 5 Shorea species (S. leprosula, S. parvifolia, Shorea johonensis, Shorea macrophylla, and Shorea platyclados) (HARDIANSYAH et al., 2006). In SBK, wild seedlings (wildlings) are collected in the natural rainforest surrounding the concession area, Bukit Baka Bukit Raya National Park. After being maintained in the nursery for 10 months, the wildlings are planted according to the TPTJ system (Fig. 2). For the present analysis, 211 leaves from six plantation stands of $S$. leprosula

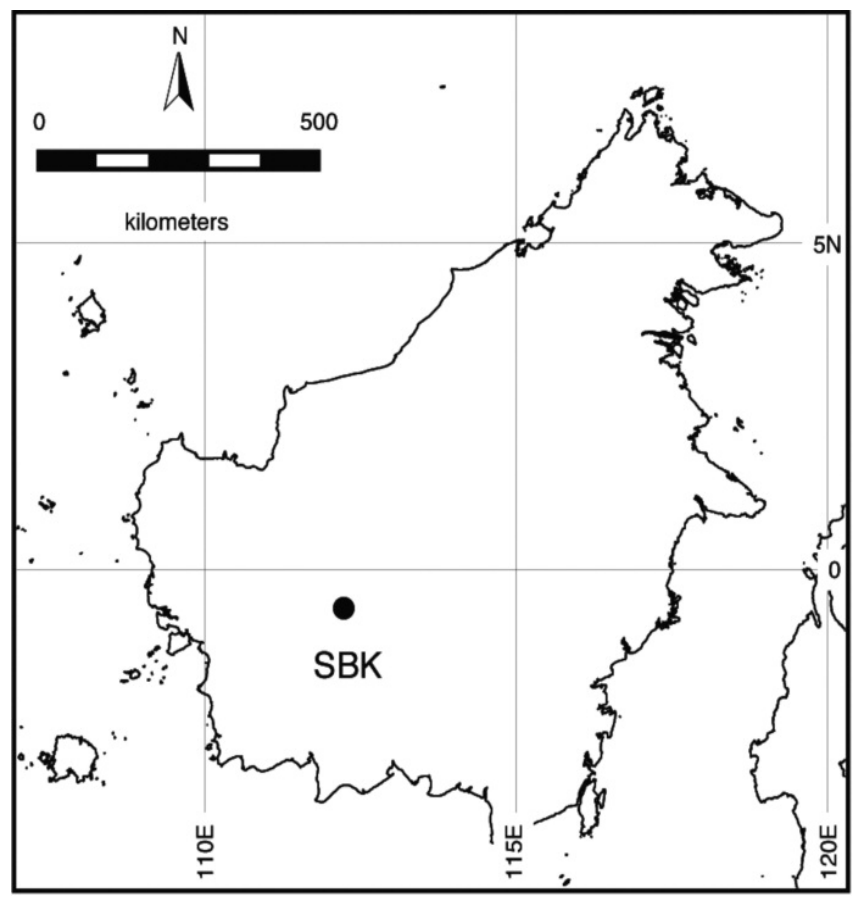

Figure 1. - Location of PT. Sari Bumi Kusuma (SBK) in Central Kalimantan, Indonesia.
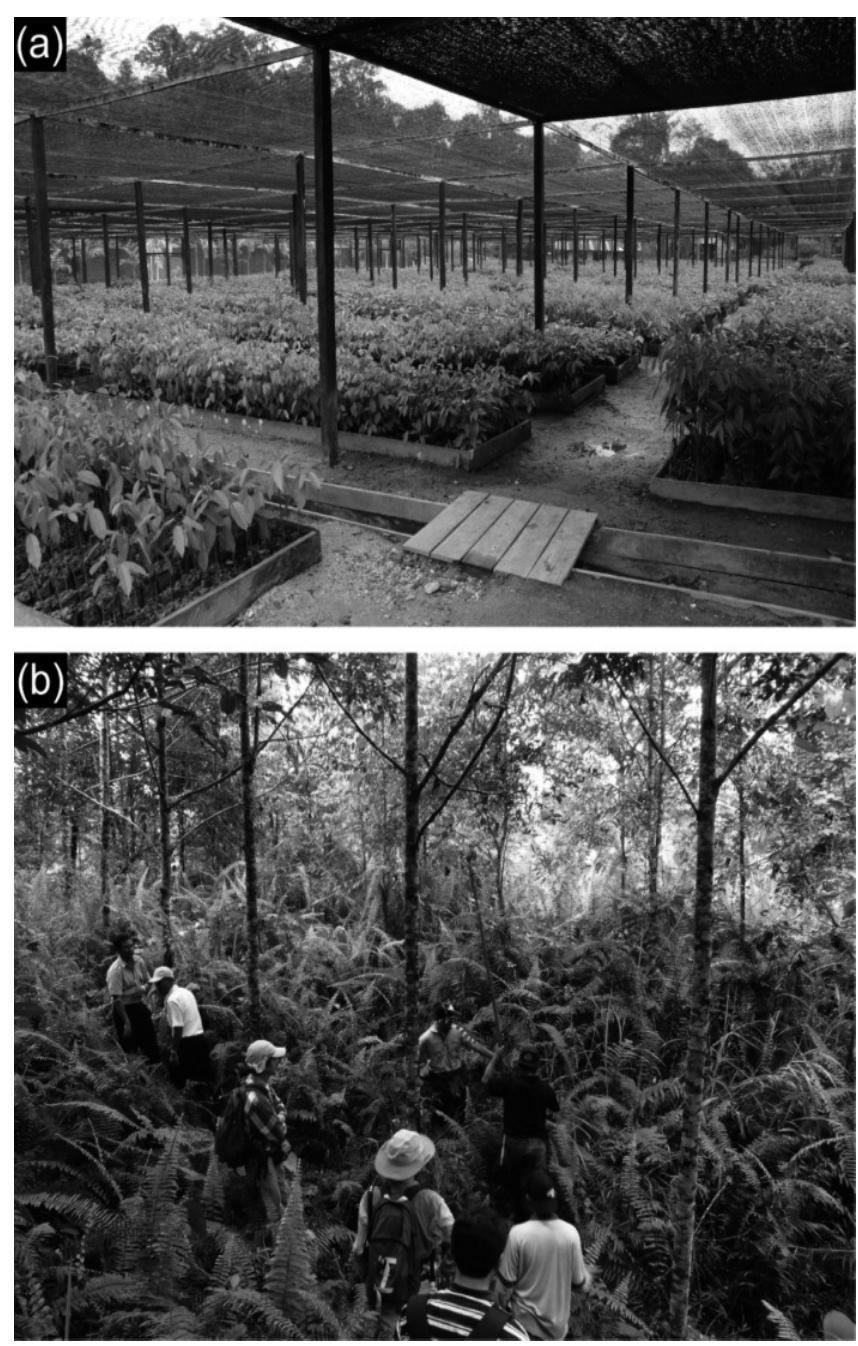

Figure 2. - (a) A nursery of Shorea leprosula and (b) a plantation stand of S. leprosula established in 2006 in SBK. 
Table 1. - Summary of chi-square tests for Hardy-Weinberg equilibrium for each locus in each population.

\begin{tabular}{|c|c|c|c|c|c|c|c|c|c|c|c|c|}
\hline \multirow[b]{2}{*}{ Locus } & \multicolumn{7}{|c|}{ S. leprosula } & \multicolumn{5}{|c|}{ S.parvifolia } \\
\hline & LNF & Lpl_2000 & Lpl_2003 & Lpl_2005 & Lp]_2006 & Lpl_2007 & Lpl_2008 & PNF & Ppl_2005 & Ppl_2006 & Ppl_2008_A & Ppl_2008_B \\
\hline SleE08 & $\mathrm{ns}$ & $\mathrm{ns}$ & ns & $\mathrm{ns}$ & $\mathrm{ns}$ & ns & ns & $* * *$ & $\mathrm{~ns}$ & ns & ns & $\mathrm{ns}$ \\
\hline SleEO5 & $* * *$ & ***** & 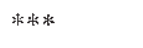 & $\mathrm{ns}$ & $\mathrm{ns}$ & 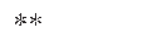 & $\mathrm{ns}$ & $* *$ & $* * * *$ & 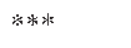 & *米水 & $* * *$ \\
\hline SleE13 & 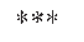 & $\mathrm{ns}$ & ns & ns & $\mathrm{ns}$ & $* * * *$ & ns & *肾亲 & *冰隶 & $\approx *$ & $\approx * *$ & $11 \mathrm{~s}$ \\
\hline SleE16 & $\mathrm{ns}$ & $* *$ & ns & $\mathrm{ns}$ & $\mathrm{ns}$ & ns & ns & $\mathrm{ns}$ & $\mathrm{ns}$ & ns & ns & ns \\
\hline SleE14 & $\mathrm{ns}$ & ns & $\mathrm{ns}$ & $\mathrm{ns}$ & $\mathrm{ns}$ & as & $\mathrm{ns}$ & $* *$ & $\mathrm{~ns}$ & $\therefore *$ & $* *$ & ns \\
\hline SleE07 & ns & ns & ns & $\mathrm{ns}$ & $\mathrm{ns}$ & ns & ns & $* *$ & $\mathrm{~ns}$ & ns & ns & ns \\
\hline SleE27 & $* * *$ & *: & ns & $\mathrm{ns}$ & $* *$ & 来水将 & ns & $* * *$ & $* * *$ & $* * * *$ & $* * *$ & $* * *$ \\
\hline Multi-locus & $*: * *$ & $* * * *$ & ns & $\mathrm{ns}$ & $* *$ & 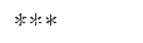 & ns & $* *:$ & $* * * *$ & $* * * *$ & $* * * 1$ & $* * *$ \\
\hline
\end{tabular}

$\mathrm{ns}=$ not significant, ${ }^{* * *} p<0.01,{ }^{* * * *} p<0.001$.

LNF: Natural forest population of S. leprosula, PNF: Natural forest population of $S$. parvifolia, Lpl: Planted populations of S. leprosula, Ppl: Planted populations of $S$. parvifolia, and numbers shown in population names indicate plantation year.

(Lpl_2000, Lpl_2003, Lpl_2005, Lpl_2006, Lpl_2007, and Lpl_2008) and 139 leaves from four populations of S. parvifolia (Ppl_2005, Ppl_2006, Ppl_2008_A, and Ppl_2008_B) (numbers shown in population names indicate planting year) were collected (Table 1). To estimate the genetic composition of these two species in natural populations, the leaves of 80 individuals of $S$. leprosula (LNF) and 41 individuals of $S$. parvifolia (PNF) were sampled from the natural forest surrounding SBK.

\section{Microsatellite analysis}

Total genomic DNA was extracted from dried leaf tissues using a modified cetyltrimethylammonium bromide (CTAB) method (MILLIGAN, 1992). All plant individuals were genotyped using seven expressed sequence taglinked microsatellite loci (EST-SSR) that were developed previously for $S$. leprosula (NG et al., 2009). Forward primers of each locus were labeled with fluorescent dyes as follows: SleE05_VIC, SleE07_PET, SleE08_6-FAM, SleE13_NED, SleE14_VIC, SleE16_PET, and SleE21_6FAM (Applied Biosystems, Life technologies Corporation, Eugene, OR, USA). Multiplex amplification reactions were performed in a total volume of $10 \mu$ containing $5 \mathrm{ng}$ of genomic DNA, $5 \mu \mathrm{l}$ of $2 \times$ Multiplex PCR Master Mix (QIAGEN Multiplex PCR Kit; Qiagen, Valencia, CA, USA), and $0.2 \mu \mathrm{M}$ of each primer. Using a GeneAmp PCR System 2700 thermal cycler (Applied Biosystems), we performed the amplification reactions under the following conditions: $1 \times\left(95^{\circ} \mathrm{C}\right.$ for $\left.15 \mathrm{~min}\right)$, $25 \times\left(94^{\circ} \mathrm{C}\right.$ for $30 \mathrm{~s}$, annealing temperature for $90 \mathrm{~s}$, $72^{\circ} \mathrm{C}$ for $\left.60 \mathrm{~s}\right)$, and $1 \times\left(60^{\circ} \mathrm{C}\right.$ for $\left.30 \mathrm{~min}\right)$. The primerpair specific annealing temperature was $45^{\circ} \mathrm{C}$ for SleE07, SleE13, SleE14, and SleE16, $45.2^{\circ} \mathrm{C}$ for SleE05 and SleE08, $50^{\circ} \mathrm{C}$ for SleE15, and $50.1^{\circ} \mathrm{C}$ for SleE21. PCR fragment sizes were determined using an ABI PRISM 3100 Genetic Analyzer (Applied Biosystems), 3130xl Genetic Analyzer (Applied Biosystems), Genotyper $^{\mathrm{TM}} 3.7$ software (Applied Biosystems), and GeneMapper $^{\mathrm{TM}} 3.0$ software (Applied Biosystems).
Assessment of Hardy-Weinberg equilibrium and linkage disequilibrium of EST-SSR markers

The assumptions of random mating and Hardy-Weinberg equilibrium for each population were tested by the $\mathrm{U}$ test and p-values were estimated with Markov chain algorithm using GenPop 4.2 (RAYMOND and RousseT, 1995). Linkage disequilibrium was tested for each pair of loci by the log likelihood ratio statistic using GenPop 4.2 (RAYMOND and RousseT, 1995).

\section{Assessment of genetic diversity and inbreeding coefficients}

Number of alleles per locus $\left(N_{\mathrm{A}}\right)$, observed heterozygosity $\left(H_{\mathrm{O}}\right)$, and expected $\left(H_{\mathrm{E}}\right)$ heterozygosity were calculated with GenAlEx 6.4 (PEAKALl et al., 2006). Allelic richness (AR; EL MousAdIK and PetIT, 1996) and inbreeding coefficient $\left(F_{\text {IS }}\right)$ were calculated using FSTAT 2.9.3.2 (Goudet, 1995). Differences in $A_{\mathrm{R}}, H_{\mathrm{O}}$, and $H_{\mathrm{E}}$ between each populations and natural population were tested using ANOVA and Tukey's multiple comparisons test using values for each locus as a replicate in $\mathrm{R}(\mathrm{R}$ Development Core Team, 2010). Deviation of $F_{\text {IS }}$ values from zero was evaluated by a significant deficit of heterozygotes for each population at 0.05 of significance levels adjusted by Bonferroni correction for multiple testing using FSTAT 2.9.3.2 (GoUDET, 1995).

\section{Assessment of genetic differentiation between populations}

To clarify the level of genetic differentiation between populations, Nei's $D$ (NEI, 1978) and $G{ }^{\prime \prime}{ }_{\text {ST }}$ (MEIRMANS and HEDRICK, 2011) were calculated for each pair of populations using GenoDive 2.0 b24 (MeIRMans and TienDERER, 2004). Pairwise differentiations were tested with the log-likelihood G-statistics by 999 permutations on GenoDive 2.0 b24 (MEIRMANs and TiEnderer, 2004) and p-values were adjusted by Bonferroni correction. An analysis of molecular variance (AMOVA; ExCOFFIER et 
al., 1992) was used to partition the entire genetic variance into those within and among populations using GenAlEx v6.4 (PEAKALL et al., 2006). To estimate the number of populations providing genetic sources, a Bayesian cluster analysis was applied to all individuals using STRUCTURE 2.3 (PRITCHARD et al., 2000). An admixture model that assumed correlated allele frequencies among populations was used. Ten runs for each $K(K=1-10)$ for each species were carried out. For each run, the number of burn-in and MCMC interactions were 100,000 and $1,000,000$, respectively. The most likely number of clusters was selected by comparing the log
$\operatorname{Pr}(\mathrm{X} \mid \mathrm{K})[\ln \mathrm{P}(\mathrm{D})]$ and the statistic delta $K$ (EvanNo et al., 2005) in each $K$. For $S$. parvifolia, the data did not fulfill the assumptions of Hardy-Weinberg equilibrium; therefore clustering analysis was not conducted.

\section{Results}

Hardy-Weinberg equilibrium and linkage

disequilibrium of EST-SSR markers

Significant deviation $(p<0.01)$ from Hardy-Weinberg equilibrium was detected in four populations of $S$. leprosula and all populations of S. parvifolia (Table 1). Ran-

Table 2. - Summary of log likelihood ratio statistic tests for linkage disequilibrium in Shorea leprosula (above diagonal) and S. parvifolia (below diagonal).

\begin{tabular}{llllllll}
\hline & SleE08 & SleE05 & SleE13 & SleE76 & SleE74 & SleE07 & SleE27 \\
\hline SleE08 & - & $\mathrm{ns}$ & $\mathrm{ns}$ & $\mathrm{ns}$ & $\mathrm{ns}$ & $*$ & $\mathrm{~ns}$ \\
SleE05 & $:$ & - & $\mathrm{ns}$ & $\mathrm{ns}$ & $\mathrm{ns}$ & $\mathrm{ns}$ & $\mathrm{ns}$ \\
SleE13 & $*$ & $*$ & - & $\mathrm{ns}$ & $\mathrm{ns}$ & $*$ & $*$ \\
SleE76 & $*$ & $*$ & $*$ & - & $\mathrm{ns}$ & $\mathrm{ns}$ & $\mathrm{ns}$ \\
SleE14 & $*$ & $*$ & $\mathrm{~ns}$ & $*$ & - & $\mathrm{ns}$ & $\mathrm{ns}$ \\
SleE07 & $*$ & $*$ & $\mathrm{~ns}$ & $\mathrm{~ns}$ & $\mathrm{~ns}$ & - & $\mathrm{ns}$ \\
SleE21 & $*$ & $*$ & $*$ & $\mathrm{~ns}$ & $*$ & $\mathrm{~ns}$ & - \\
\hline
\end{tabular}

$\mathrm{ns}=$ not significant, ${ }^{*} p<0.05$.

Table 3. - Genetic diversity within each population of Shorea leprosula and $S$. parvifolia.

\begin{tabular}{lllllllll}
\hline Species & Population & $N$ & $N \mathrm{a}$ & $A_{\mathrm{R}}$ & $H_{\mathrm{O}}$ & $H_{\mathrm{E}}$ & $F_{\mathrm{IS}}$ \\
\hline Shorea leprosula & I.NF & 80 & 1.3 & $9.90^{\mathrm{ab}}$ & 0.66 & $0.76^{\mathrm{ab}}$ & $0.13^{*}$ \\
& Lpl_2000 & 33 & 11 & $11.14^{\mathrm{a}}$ & 0.71 & $0.81^{\mathrm{a}}$ & $0.15^{*}$ \\
& Lpl_2003 & 34 & 10 & $10.21^{\mathrm{ab}}$ & 0.76 & $0.78^{\mathrm{ab}}$ & 0.05 \\
& Lpl_2005 & 35 & 10 & $9.55^{\mathrm{ab}}$ & 0.71 & $0.78^{\mathrm{b}}$ & 0.06 \\
& Lpl_2006 & 35 & 10 & $9.57^{\mathrm{ab}}$ & 0.74 & $0.77^{\mathrm{ab}}$ & 0.05 \\
& Lpl_2007 & 37 & 10 & $9.49^{\mathrm{b}}$ & 0.71 & $0.77^{\mathrm{ab}}$ & 0.09 \\
& I.pl_2008 & 37 & 10 & $9.53^{\mathrm{b}}$ & 0.75 & $0.77^{\mathrm{ab}}$ & 0.04 \\
& PNorea parvifolia & 41 & 12 & $11.23^{\mathrm{c}}$ & 0.60 & $0.78^{\mathrm{cd}}$ & $0.25^{*}$ \\
& PNF & 47 & 11 & $9.74^{\mathrm{al}}$ & 0.60 & $0.76^{\mathrm{ad}}$ & $0.22^{*}$ \\
& Ppl_2005 & 30 & 8 & $7.86^{\mathrm{d}}$ & 0.52 & $0.71^{\mathrm{c}}$ & $0.28^{*}$ \\
& Ppl_2008_A & 32 & 11 & $10.42^{\circ}$ & 0.59 & $0.78^{\mathrm{dd}}$ & $0.26^{*}$ \\
& Ppl_2008_B & 30 & 9 & $9.14^{\mathrm{ad}}$ & 0.67 & $0.77^{\mathrm{cd}}$ & $0.15^{*}$ \\
\hline
\end{tabular}

Sample size $(N)$; mean number of alleles per locus $\left(N_{\mathrm{a}}\right)$; allelic richness $\left(A_{\mathrm{R}}\right)$; observed $\left(H_{\mathrm{O}}\right)$ and expected heterozygosity $\left(H_{\mathrm{E}}\right)$; inbreeding coefficient $\left(F_{\text {IS }}\right)$. LNF: Natural forest population of $S$. leprosula, PNF: Natural forest population of $S$. parvifolia, Lpl: Planted populations of $S$. leprosula, Ppl: Planted populations of $S$. parvifolia, and numbers shown in population names indicate plantation year. Different lowercase letters above the values indicate significant $p<0.05$ differences among populations. Asterisks indicate $F_{\text {IS }}$ values are significantly different from $0(p<0.05)$. 
Table 4. $-G_{\text {ST }}^{\prime \prime}$ values (above diagonal) and Nei's $D$ (below diagonal) for every pairwise populations of (a) Shorea leprosula and (b) S. parvifolia.

(a) S. leprosula

\begin{tabular}{lccrrrrr}
\hline & LNF & Lpl_2000 & Lpl_2003 & Lpl_2005 & Lpl_2006 & Lpl_2007 & Lpl_2008 \\
\hline LNF & - & $0.098^{*}$ & 0.010 & $0.065^{*}$ & $0.053^{*}$ & $0.037^{*}$ & $0.080^{*}$ \\
Lpl_2000 & 0.075 & - & 0.052 & $0.078^{*}$ & $0.090^{*}$ & $0.073^{*}$ & $0.119^{*}$ \\
Lpl_2003 & 0.007 & 0.047 & - & $0.053^{*}$ & $0.090^{*}$ & $0.049^{*}$ & $0.080^{*}$ \\
Lpl_2005 & 0.055 & 0.058 & 0.042 & - & $0.110^{*}$ & $0.078^{*}$ & $0.136^{*}$ \\
Lpl_2006 & 0.044 & 0.076 & 0.077 & 0.092 & - & 0.022 & $0.116^{*}$ \\
Lpl_2007 & 0.032 & 0.062 & 0.043 & 0.066 & 0.021 & - & $0.036^{*}$ \\
Lp]_2008 & 0.067 & 0.101 & 0.068 & 0.116 & 0.100 & 0.032 & - \\
\hline
\end{tabular}

(b) S. parvifolia

\begin{tabular}{lccrrr}
\hline & PNF & Ppl_2005 & Ppl_2006 & Ppl_2008_A & Ppl_2008_B \\
\hline PNF & - & $0.101^{*}$ & $0.071^{*}$ & $0.045^{*}$ & 0.002 \\
Ppl_2005 & 0.093 & - & $0.100^{*}$ & $0.067^{*}$ & $0.087^{*}$ \\
Ppl_2006 & 0.058 & 0.085 & - & 0.068 & $0.109^{*}$ \\
Ppl_2008_A & 0.050 & 0.065 & 0.055 & - & 0.023 \\
Ppl_2008_B & 0.012 & 0.080 & 0.091 & 0.030 & - \\
\hline
\end{tabular}

* Significant population differentiation at 0.05 of significance level adjusted by Bonferroni correction for multiple testing.

dom mating within most populations was found in $S$. leprosula but not in $S$. parvifolia. Linkage disequilibrium was detected in three locus pairs (14\%) in S. leprosula and 15 locus pairs (74\%) in S. parvifolia (Table 2). Near-complete independence of the seven loci was shown in S. leprosula but not in $S$. parvifolia, suggesting a relatively high rate of inbreeding within each population.

\section{Genetic diversity and inbreeding coefficients}

The degree of genetic diversity and inbreeding coefficient for each population of S. leprosula and S. parvifolia is presented in Table 3. The degree of genetic diversity $\left(A_{\mathrm{R}}, H_{\mathrm{O}}\right.$, and $\left.H_{\mathrm{E}}\right)$ in each plantation was not signifi- cantly different from the natural population in either species except for a difference in $A_{\mathrm{R}}$ between Ppl_2006 and PNF in S. parvifolia. Two populations of $S$. leprosu$l a$ and all populations of $S$. parvifolia presented significantly high $F_{\text {IS }}$ values.

\section{Genetic differentiation between populations}

In $S$. leprosula, $G{ }_{\text {ST }}$ and Nei's $D$ values between each plantation and natural population were 0.057 on average (range: $0.010-0.098$ ) and 0.047 on average (range: 0.007-0.075), respectively (Table 4 (a)). In S. parvifolia, $G{ }^{\prime \prime}$ and Nei's $D$ values between each plantation and natural population were 0.055 on average (range: $0.002-0.101$ ) and 0.054 on average (range: $0.012-0.093$ ),

Table 5. - Summary of analysis of molecular variance for EST-SSR genotypes.

\begin{tabular}{lrrrr}
\hline Source of variation & $d f$ & Sum of squares & Variance components & Percentage of variation \\
\hline (a) S. leprosula & & & & \\
Among populations & 6 & 70.014 & 0.166 & 2.7 \\
Within populations & 284 & 1686.776 & 5.939 & 97.3 \\
Total & 290 & 1762.790 & 6.105 & 100.0 \\
(b) S.parvifolic & & & & 3.0 \\
Among populations & 4 & 51.712 & 0.175 & 97.0 \\
Within populations & 175 & 1168.654 & 6.678 & 100.0 \\
Total & 179 & 1220.367 & 6.853 & \\
\hline
\end{tabular}




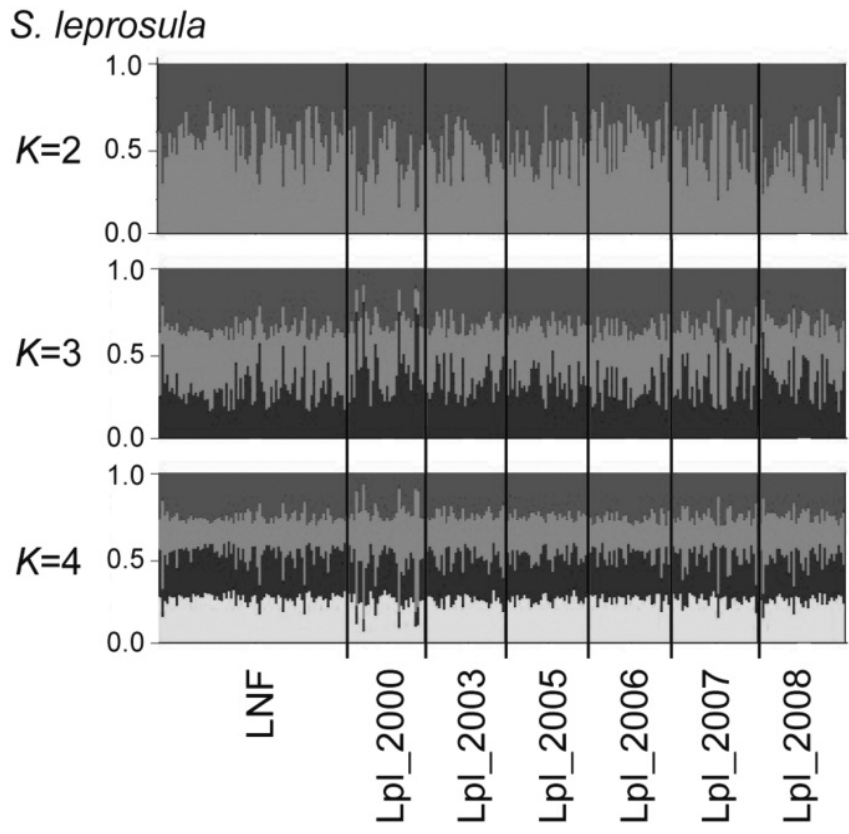

Figure 3. - Bayesian structure analysis of Shorea leprosula with the STRUCTURE software program from $K=2$ to $K=4$ (PRITCHARD et al., 2000). LNF, natural forest population of S. leprosula; Lpl, planted populations of S. leprosula. Numbers shown in the population names indicate plantation year.

respectively (Table $4(\mathrm{~b})$ ). As a result of testing population differentiation, 18 pairs of populations in S. leprosula and seven pairs in $S$. parvifolia showed significant differentiations. Ppl_2005 presented relatively large differentiation from the natural population (PNF), as shown in $G$ " ${ }_{\mathrm{ST}}$ and $D$ values of 0.101 and 0.093 , respectively (Table 4 (b)). AMOVA of hierarchical genetic diversity revealed that genetic variation within populations accounted for $97 \%$ of the total molecular variance, and $3 \%$ of the variance occurred among populations in both species (Table 5).

In the Bayesian analysis for clustering of all individuals, the $\ln P(\mathrm{D})$ value was highest at $K=1$ for $S$. leprosula. At $K>2$, each individual contained alleles derived from each cluster in a similar proportion (Fig. 3). Thus, all $S$. leprosula individuals likely originated from a single gene pool and genetic differentiations between populations were not found.

\section{Discussion}

\section{Genetic status of plantation stands in SBK}

In both Shorea leprosula and $S$. parvifolia, each plantation contained genetic diversity as large as that in the natural population (Table 3, Table 5). However, Ppl_2006 showed significantly lower allelic richness $\left(A_{\mathrm{R}}=7.86\right)$ than the natural forest (PNF, $\left.A_{\mathrm{R}}=11.23\right)$, the smallest value of observed heterozygosity $\left(H_{\mathrm{O}}=0.52\right)$, and the largest inbreeding coefficient $\left(F_{\text {IS }}=0.28\right)$ among the plantations of $S$. parvifolia (Table 3). Because the study plantations were established by selecting seedlings without genetic information, incidental lack of genetic diversity within a plantation stand could occur. It is likely that $S$. parvifolia presented a relatively high- er level of inbreeding coefficients than $S$. leprosula, and all populations of $S$. parvifolia deviated from the HardyWeinberg equilibrium (Table 3). This difference could have been affected by tree density in the wild populations from which seedlings were taken. In the wild, the density of conspecific flowering trees affects selfing rate in the population (FUKUE et al., 2007) and lower tree density drives a higher rate of inbreeding (TANI et al., 2009). As a whole, the genetic diversity contained in almost all plantation stands was as high as that in the natural population. This indicates that the current plantation methodology is suitable for maintaining genetic diversity in the planted dipterocarp trees. However, it should be noted that an incidental lack of genetic diversity could occur when the source seedlings are taken from wild populations of low density, or genetically related seedlings are transplanted from a nursery to the same plantation stand.

Significant genetic differentiations between study populations were found, indicating that genetic compositions were nonhomogenous between the plantation stands (Table 4). Genetic compositions could be different between plantation stands because the individuals may be only a part of trees in the original natural forest. However, based on the Bayesian clustering of S. leprosu$l a$, the most likely number of genetic clusters was one (Fig. 3), suggesting that the source of trees in each plantation was similar to each other. Therefore, genetic degradations and disturbance of the genetic structure probably had no importance.

\section{Implication for the dipterocarp plantations in the tropical rainforest}

Based on TPTJ, the current plantation method incorporates several factors that may contribute to the maintenance of genetic diversity in plantations. One of these factors is the use of wild seeds and seedlings collected from the natural forest surrounding the concession area. Unlike clonal propagation such as cutting, wild seeds and seedlings derived from natural regeneration are likely to maintain a high degree of genetic diversity. Another factor is the presence of a healthy, natural forest surrounding the concession area, which facilitates the easy collection of seeds and seedlings. Because S. leprosula and S. parvifolia are outcrossing species (LEE et al., 2000; SAKAI et al., 1999) and planted populations may influence the genetic composition of natural populations through gene flow, it is safe to plant seedlings derived from a neighboring natural population. Conservation of the natural forest near the concession area is an advisable policy for the maintenance of the forest landscape and the sustainability of the forestry industry.

To maintain the current genetic status in the plantation stands, appropriate method to select seedlings for plantation is important. The process that may cause the reduction of genetic variation such as selection for specific phenotypic traits or propagation by cutting should be avoided. By mixing the seedlings that originated from different mother trees, we can expect that plantation stands containing high genetic diversity similar to the natural forests may be established and the reduc- 
tion of the genetic diversity in the process of transplantation of seedlings from nurseries to plantation stands may be prevented.

The sustainability of dipterocarp plantation stands is ecologically and economically important. Ecologically, dipterocarp plantations contribute to ecological services such as the conservation of biodiversity (BARLOW et al., 2007; MEIJAARD and SHEIL, 2007), the storage of carbon (KetTle, 2010). The timber production provides an important income for rural people. Although some plantation systems including TPTJ have been established after repeated improvements, their genetic effectiveness has not been recognized. We report the first genetic evaluation of an intensive enrichment planting system practiced in Indonesia, TPTJ and conclude that the current plantation methodology is basically suitable for maintaining the genetic variation present in natural populations. The continuance and improvement of dipterocarp plantation techniques, with regard to genetic effects are expected.

\section{Acknowledgements}

We would like to thank Prof. MAMORU KANZAKI, the staffs at SBK, Hatma Suryatmojo, Ruliyana Susanti, Dr. Michimasa Yamasaki, and Tomoya Inada. This research was supported by the project "Creation of the paradigm of sustainable use of tropical rainforest by the intensive forest management and advanced utilization of forest resources" funded by the Strategic Funds for the Promotion of Science and Technology from the Japan Science and Technology Agency.

\section{References}

Adjers, G. and A. OTsAmo (1996): Seedling production methods of dipterocarps, pp. 391-410. In: Dipterocarp forest ecosystems towards sustainable management, edited by A. Schulte and D. Schone, World Publishing Co. Pte. Ltd., Singapore.

APPANAH, S. (1998): Management of natural forests, pp. 133-149. In: A review of dipterocarps taxonomy, ecology, silviculture, edited by S. APPANAH and J. M. TURNBULL, Center for International Forestry Research, Bogor, Indonesia.

AshTON, P. S. (2004): Dipterocarpaceae. pp. 63-388. In: Tree Flora of Sabah and Sarawak, vol. 5, edited by E. Soepadmo, L. G. SaW, and R. C. K. Chung, Forest Research Institute Malaysia, Kuala Lumpur, Malaysia.

Barlow, J., T. A. Gardner, I. S. Araujo, T. C. Avila-Pires, A. B. Bonaldo, J. E. Costa and M. C. Esposito et al. (2007): Quantifying the biodiversity value of tropical primary, secondary, and plantation forests. Proceedings of the National Academy of Sciences of the United States of America 104: 18555-18560.

BAWA, K. S. (1998): Conservation of genetic resources in the Dipterocarpaceae. In: Review of the dipterocarps: taxonomy, ecology, silviculture, edited by S. APPANAH and J. M. TURNBULL, CIFOR, Bogor, Indonesia.

Berry, N. J., O. L. Phillips, S. L. Lewis, J. K. Hill, D. P. Edwards, N. B. TAWATAO and N. Ahmad et al. (2010): The high value of logged tropical forests: lessons from northern Borneo. Biodiversity and Conservation 19 985-997.
Bradshaw, C. J. A., N. S. Sidhi and B. W. Brook (2009): Tropical turmoil: a biodiversity tragedy in progress. Frontiers in Ecology and the Environment 7: 79-87.

Crutsinger, G. M., M. D. Collins, J. A. Fordyce, Z. GomPERT, C. C. NiCE and N. J. SANDERS (2006): Plant genotypic diversity predicts community structure and governs an ecosystem process. Science 313: 966-968.

Elmousadik, A. and R. J. Petit (1996): High level of genetic differentiation for allelic richness among populations of the argan tree Argania spinosa (L.) Skeels endemic to Morocco. Theoretical and Applied Genetics 92: 832-839.

Evanno, G., S. Regnaut and J. Goudet (2005): Detecting the number of clusters of individuals using the software STRUCTURE: a simulation study. Molecular Ecology 14: 2611-2620.

Excoffier, L., P. E. Smouse and J. M. Quattro (1992): Analysis of molecular variance inferred from metric distances among DNA haplotypes - Application to human mitochondrial-DNA restriction data. Genetics 131: $479-491$.

Fisher, B., D. P. Edwards, X. L. Giam and D. S. Wilcove (2011a): The high costs of conserving Southeast Asia's lowland rainforests. Frontiers in Ecology and the Environment 9: 329-334.

Fisher, B., D. P. Edwards, T. H. LARsen, F. A. Ansell, W. W. Hsu, C. S. Roberts and D. S. Wilcove (2011b): Cost-effective conservation: calculating biodiversity and logging trade-offs in Southeast Asia. Conservation Letters 4: 443-450.

FrankHAM, R. (1995): Conservation genetics. Annual Review of Genetics 29: 305-327.

Fukue, Y., T. Kado, S. L. Lee, K. K. S. NG, N. Muhammad and Y. TSUmuRA (2007): Effects of flowering tree density on the mating system and gene flow in Shorea leprosula (Dipterocarpaceae) in Peninsular Malaysia. Journal of Plant Research 120: 413-420.

GoudET, J. (1995): FSTAT (Version 1.2): A computer program to calculate F-statistics. Journal of Heredity $\mathbf{8 6}$ : $485-486$

Hardiansyah, G., T. Hardjanto and M. Mulyana (2006): A brief note on TPTJ (Modified Indonesia Selective Cutting System) from experience of PT Sari Bumi Kusuma (PT SBK) timber concessionair, pp. 23-31. In: Permanent sample plots: More than just forest data, edited by H. Priyadi, P. Gunarso, and M. KAnninen, Center for International Forestry Research, Bogor, Indonesia.

Hufford, K. M. and S. J. MAzer (2003): Plant ecotypes: genetic differentiation in the age of ecological restoration. Trends in Ecology \& Evolution 18: 147-155.

ITTO (2005): Status of Tropical Forest Management. International Tropical Timber Organization, Yokohama, Japan.

KetTle, C. J. (2010): Ecological considerations for using dipterocarps for restoration of lowland rainforest in Southeast Asia. Biodiversity and Conservation 19: 1137-1151.

Kettle, C. J., J. Ghazoul, P. Ashton, C. H. Cannon, L. CHONG, B. DiwaY and E. FARIDAH et al. (2011): Seeing the fruit for the trees in Borneo. Conservation Letters 4: 184-191.

LeE, S. L., R. Wickneswari, M. C. MAhani and A. H. ZaKRI (2000): Mating system parameters in a tropical tree species, Shorea leprosula Miq. (Dipterocarpaceae), from Malaysian lowland dipterocarp forest. Biotropica 32: 693-702. 
LinHART, Y. B. and M. C. GRANT (1996): Evolutionary significance of local genetic differentiation in plants. Annual review of ecology and systematics 27: 237-277.

MEIJAARD, E. and D. SHeIL (2007): A logged forest in Borneo is better than none at all. Nature 446: 974-974.

MEIRMANs, P. G. and P.W. HEDRICK (2011): Assessing population structure: $F_{\mathrm{ST}}$ and related measure. Molecular Ecology Resources 11: 5-18.

MEIRMANs, P. G. and P. H. VAN TiEndeREN (2004): GENOTYPE and GENODIVE: two programs for the analysis of genetic diversity of asexual organisms. Molecular Ecology Notes 4: 792-794.

Milligan, B. (1992): Plant DNA isolation, pp. 59-88. In: Molecular genetic analysis of populations: a practical approach, edited by A. R. HoElzEL. IRL Press, Oxford.

MINISTRY OF FORESTRY (1998): Decree no: 625/Kpts-II/1998: The Silvicultural System of Selective Cutting and Strip Planting (TPTJ) Silviculture System in The Management of Natural production Forests, Jakarta, Indonesia.

MinistRY OF ForestRY (2005): Decree no: 226/VIBPHA/2005: The Guideline of Indonesia Selective Cutting and Intensive Planting System (Tebang Pilih Tanam Indonesia Intensif / TPTII); Directorate General of BPK, Jakarta, Indonesia.

MINISTRY OF FoRESTRY (2009): Decree no: 11/MenhutII/2009: Silvicultural System in The Natural Forest productions, Jakarta, Indonesia.

Myers, N., R. A. MittermeieR, C. G. Mittermeier, G. A. B. DA Fonseca and J. Kent (2000): Biodiversity hotspots for conservation priorities. Nature 403 : 853-858.

NEI, M. (1978): Estimation of average heterozygosity and genetic distance from a small number of individuals. Genetics 89: 583-590.

NG, F. S. P. (1977): Gregarious flowering of dipterocarps in Kepong 1976. Malaysian Forester 40: 126-137.

NG, K. K. S., S. L. Lee, Y. Tsumura, S. Ueno, C. H. Ng and C. T. LEE (2009): Expressed sequence tag-simple sequence repeats isolated from Shorea leprosula and their transferability to 36 species within the Dipterocarpaceae. Molecular Ecology Resources 9: 393-398.
O'Brien, E. K. and S. L. Krauss (2010): Testing the Home-Site Advantage in Forest Trees on Disturbed and Undisturbed Sites. Restoration Ecology 18: 359-372.

PeAkall, R. and P. E. SMouse (2006): GENALEX 6: genetic analysis in Excel - Population genetic software for teaching and research. Molecular Ecology Notes 6: 288-295.

Potts, B. M., R. C. Barbour, A. B. Hingston and R. E. VAILLANCOURT (2003): Genetic pollution of native eucalypt gene pools - identifying the risks. Australian Journal of Botany 51: 1-25.

Pritchard, J. K., M. Stephens and P. Donnelly (2000): Inference of population structure using multilocus genotype data. Genetics 155: 945-959.

RAYMOND, M. and F. RousseT (1995): GENEPOP (version 1.2): population genetics software for exact tests and ecumenicism. Journal of Heredity 86: 248-249.

R Development Core Team (2010): R: A language and environment for statistical computing. website: URL http://www.R-project.org/.

SaKaI, S., K. Momose, T. Yumoto, M. Kato and T. Inoue (1999): Beetle pollination of Shorea parvifolia (section Mutica, Dipterocarpaceae) in a general flowering period in Sarawak, Malaysia. American Journal of Botany 86: 62-69.

SASAKI, S. (1980): Storage and germination of dipterocarp seeds. Malaysian Forester 43: 290-308.

Sovu, M. Tigabu, P. Savadogo, P. Odén and L. Xayvongsa (2010): Enrichment planting in a logged-over tropical mixed deciduous forest of Laos. Journal of Forestry Research 21: 273-280.

Tani, N., Y. Tsumura, T. Kado, Y. Taguchi, S. L. Lee, N. Muhammad, K. K. S. NG, S. Numata, S. Nishimura, A. KonUma and T. OKUdA (2009): Paternity analysisbased inference of pollen dispersal patterns, male fecundity variation, and influence of flowering tree density and general flowering magnitude in two dipterocarp species. Annals of Botany 104: 1421-1434.

TompSETT, P. B. (1987): Desiccation and storage studies on Dipterocarpus seeds. Annals of Applied Biology 110: 371-379. 